\title{
Regional Initiatives and US Trade Policy in Asia
}

\author{
Gary R. Saxonhouse*
}

\begin{abstract}
This article gives an account of US trade policy towards Asia, with particular reference to regional preferential trading agreements. The outcome of fifteen years of US pursuit of regional trade policies could possibly be a network of preferential trade arrangements centred around the USA; a more likely outcome is an increasingly strengthened multilateral system based on the World Trade Organisation (WTO). A stronger WTO may prove capable of constraining even its most powerful members. This outcome is certainly in the long-term interest of the USA.
\end{abstract}

In the mid-1980s, US trade policy embraced regional trading arrangements as a tactic to promote a new round of multilateral trade negotiations. What began as a tactical ploy is widely seen as having become an end in itself with the USA increasingly attempting to position itself at the hub of a system where a number of potentially important regional trading associations could be thought of as its spokes (Lipsey 1990; Wonnacott 1990; Anderson and Snape 1994).

Such a hub-and-spoke approach to the international trading system may have economic advantages for the USA. Exports from the USA have preferences in the spoke markets. Exports from countries in different spokes face discrimination in competing with duty-free exports from the USA. Similarly, only firms in the USA have access to duty-free imported inputs from all spokes. Inevitably, with these trade advantages, the USA becomes a favoured location for production, and investment is diverted there.

Whatever advantages the USA might obtain from a hub-and-spoke system, that are not obtained from a multilateral trading arrangement embracing all spokes together, must come at the expense of spoke countries. The maintenance of barriers between countries in a hub-and-spoke system which would not be present in a comprehensive multilateral trading system involves a decline in global welfare even while the USA might be better off.

This significant change in US trade policy has facilitated the formation of the Asia Pacific Economic Cooperation (APEC) forum. At the time of its founding in 1989 and through its early annual ministerial meetings, APEC leaders emphasised that whatever trade liberalisation might be undertaken would not discriminate against non-members (Snape 1996). Increasingly, however, it has been the apparent goal of US trade policy to see APEC evolve into a preferential trading arrangement. Whether this is being done as an end in itself, or whether this goal for APEC is being suggested as a threat to encourage multilateral liberalisation on the part of the EU remains to be seen (Bergsten forthcoming; Elek and Soesastro 1997).

* Department of Economics, University of Michigan, Ann Arbor, Michigan. Jagdish Bhagwati provided very helpful, detailed comments on the first draft of this paper. Two anonymous referees also provided very useful comments. 


\section{The initial US interest in preferential trading arrangements not directed at Asia}

The failure of the GATT Ministerial in November 1982 to launch a new round of multilateral trade negotiations triggered a historically unprecedented US interest in regional trade agreements. In 1983, the US Trade Representative (USTR) commenced negoti- ations for bilateral preferential trading agreements (PTAs) with both Canada and Israel. Seemingly, these proposed bilateral trading arrangements marked a dramatic departure from the multilateralism that had been the cornerstone of US trade policy for the preceding forty years. Howard Ellis spoke for US economic policy-makers in 1945 when he noted:

There are good reasons for believing that no device portends more restrictions of international trade in the postwar setting than bilateral trade arrangements (Ellis 1945:2).

US trade officials denied in 1983 that these new regional trade initiatives meant any lessening of US support for a multilateral trading system. Rather, foreshadowing statements on trade policy that are now routine, they argued that these initiatives would put pressure on the reluctant contracting parties of the GATT to commence a new round of multilateral trade negotiations, and also create more than enough new commercial opportunities for other American trading partners to far outweigh the diversion of trade that might occur. ${ }^{1}$

In any event, the Reagan administration proclaimed at the time that this shift in trade policy was not meant to be parochial. The bilateral agreements with Canada and Israel were intended as a prelude to a world-wide search for new candidates for bilateral PTAs with the USA (Bhagwati 1993).

\section{Persistent US regionalism}

Whether because of the incipient bilateralism of US trade policy or because of developments in Europe, the Western Pacific and elsewhere, a new round of multilateral trade negotiations did begin under the framework of the Uruguay Round. Once started down the road to regionalism, however, US trade policy-makers have shown little inclination to turn back. Successive administrations have appeared ever more eager to use preferential trading arrangements as a critical element of trade policy realpolitik. The Economic Community's grandiose plans (to complete in 1992 what had begun in 1957 with the Treaty of Rome) helped sway the Bush administration to do more than just agree to the ardent desire of President Salinas of Mexico to NAFTA-ise the Canadian-USA Free Trade Agreement. It also led the Bush administration to shelve the pretence of a world-wide search for new candidates for bilateral PTAs by making the extension of NAFTA to the rest of the Western Hemisphere its chief PTA objective (Bhagwati 1993).

\section{The Hawke initiative}

No sooner had the Bush administration expressed considerable interest in what would later be called the 'Enterprise for the Americas' preferential trade area than the concern expressed outside the Western hemisphere led it to reconsider its tactics. Burgeoning interest in the Hawke initiative for a Pacific trading arrangement (which had been announced by the Australian prime minister in January 1989 in Seoul), without first consulting the USA, kindled fears in Washington that in tying itself closely to preferential trading relationships in the Western hemisphere the Bush administration ran the risk of triggering trade-diverting responses elsewhere in the Pacific Basin. ${ }^{2}$ In the interest of improving access to economies

1 The first argument is distinguished as the "dynamic time path effect" by Bhagwati and Panagariya (1996). This effect is seen as benign by US trade officials whereas Bhagwati and Panagariya consider this view to be unjustified. See also the theoretical treatment in Saxonhouse (1993a, 1993b).

2 Consequences of the world dividing into three preferential trading arrangements first began receiving theoretical treatment at this time. See, for example, Krugman (1991). More concrete discussion of this problem appears in Thurow (1992). 
elsewhere in the Western hemisphere, there was concern that US trade policy might ultimately impair access to far larger markets in the Western Pacific.

While the Bush administration, with its strong base in Texas, was unwilling to drop its plans for PTAs in the Western hemisphere, particularly those with Mexico, it was prepared to deal directly with some of the ill-will that had been generated in East Asia by thenPresidential candidate Bush's role in the passage of the Super-301-laden Trade Bill of $1988 .{ }^{3}$ In the first instance, this meant en- suring for itself a place at the conference table in Canberra for the founding of the Hawke initiative-inspired APEC process. To the satisfaction of the Bush administration, APEC drew its membership from the Western hemisphere as well as from the Western Pacific.

A year later, in a continuing effort to ensure that any PTA involving the Western Pacific's major economies be pan-Pacific, Secretary of State Baker, at the second meeting of APEC in Seoul, discouraged the formation of the (exclusively Asian) East Asian Economic Group first proposed that same month by Malaysia's Prime Minister Mahathir. Ironically, Secretary Baker, at that time championing a trading arrangement in the Western hemisphere that excluded extra-regional members, was prepared to deny East Asia its own exclusive trading arrangement. Unable to stop its formation but assured of its exclusively consultative role, Secretary Baker still was able to prevent Japan and Korea from endorsing the Mahathir grouping (Saxonhouse 1993b; Petri 1993).

\section{Conclusion of the Uruguay Round}

The Bush administration left office in January 1993, unable to reach the agreement with the European Community on agricultural subsidies that would permit the successful conclusion of the Uruguay Round. As negotiations dragged on through 1993, almost three years after the expected conclusion of the Round, the Clinton administration, emulating the Reagan administration, sought to make tactical use of PTAs to promote further development of the multilateral trading system. In particular, the Clinton administration attempted to make use of the fortuitous timing of both the NAFTA debate in the US Congress and its hosting of the APEC ministerial meeting in Seattle in late 1993 to remind Europeans of the fragility of the multilateral approach to international trading relationships.

NAFTA, by itself, was too small to be of major concern to the Europeans. APEC, however, embraced economies which, in aggregate in 1992, had a GDP almost twice as large as the EU. In an effort to give some enhanced visibility to APEC, whose trade facilitation and trade liberalisation accomplishments in its first four years of existence had been negligible, the Clinton administration convened an informal heads of state meeting following the formal APEC ministerial. More importantly, in a new departure, APEC's American-led Eminent Persons Group suggested that APEC be used as a framework within which free trade in the AsianPacific region might be achieved (Snape 1996).

Within weeks of the conclusion of the APEC Seattle meeting, seven and a half years of negotiations of the Uruguay Round ended in a far-reaching agreement. While there is no independent evidence to support this claim, many in APEC have been quick to suggest the successful Seattle meeting's influence on the outcome of these multilateral negotiations (Funabashi 1995; Bergsten, forthcoming). ${ }^{4}$

After Seattle, as in the mid-1980s and whether or not the renewed interest shown in PTAs was largely tactical, regionalism took on a life of its own for US trade policy-makers. The recommendations for trade liberalisation made

3 Super-301 provided that the USTR could name countries as unfair trading partners. Barriers to specific commodities listed for these countries had to be negotiated away following the designation, and if the progress made was determined to be insufficient the US government could impose retaliatory measures. The Reagan White House dropped its fight against the inclusion of Super-301 in the Trade Bill of 1988 at the request of the Bush campaign just prior to the Michigan presidential primary election in March of that year.

4 More recently, APEC leaders have also been quick to claim credit for bringing the December 1996 Information Technology Agreement and WTO Agreement on Basic Telecommunication Services to a successful conclusion (APEC 1997). 
by the Eminent Persons Group in their initial report to the Seattle Ministerial were not accepted. Nevertheless, impressed by the respect shown by the EU for the potential economic consequences of an Asian-Pacific PTA, many Americans with an interest in trade policy, both in and out of government, were eager to maintain this as a viable option for APEC. The Clinton administration, however, faced lack of interest bordering on hostility on the part of the governments of most of the East Asian countries for any effort that would use APEC as the locus for negotiating preferential trade liberalisation (Soesastro 1995).

The Clinton administration sought in early 1994 to counteract East Asian reluctance to use APEC as a negotiating body with yet another regional strategy. Instead of extending NAFTA exclusively southward as envisaged in the Bush administration's Enterprise for the Americas plan, the Clinton administration began discusing extending NAFTA across the Pacific as well (Manning and Stern 1994)..$^{5}$ For example, as the Nihon Keizai Shimbun speculated in May 1994:

South Korea and the US have basically agreed that they will soon begin to take steps toward the signing of a free trade accord by 1996 or 1997, according to high-ranking Korean and US officials.

The bilateral arrangement is also designed to pave the way for South Korea to eventually join theUS, Canada and Mexico in the North American Free Trade Agreement, the officials said...

American and Korean trade officials say they worked out the deal in late March through mid-April when US Trade Representative Mickey Kantor met with South Korean Foreign
Minister Han Sung Jo and other senior officials.

The agreement was a result of each other's concessions trade officials said. The Seoul government agreed to the US demand that agriculture and finance-potentially explosive issues at home-be included (Nihon Keizai Shimbun, 1994).

The ostensible purpose of such proposals was once again to reassure US trading partners in East Asia and Oceania that the Clinton administration did not intend to draw a commercially restrictive line down the Pacific. ${ }^{6}$ In common with the contemplated southward expansion, it was suggested that NAFTA's expansion across the Pacific might also take place on a country-by-country basis. A Singapore or a Korea might be paired with a Chile.

However speculative such suggestions by the Clinton administration might have been, they could only have been unsettling to APEC members outside the Western hemisphere. In attempting to admit economies sequentially to NAFTA, US trade policy would force its APEC trading partners to compete among themselves in granting concessions in order to avoid the trade-diverting and foreign-investmentdiverting consequences of late admission or even exclusion from an enlarged NAFTA. ${ }^{7}$ The intent of such suggestions appeared to be less to reassure the USA's East Asian trading partners about NAFTA than to indicate that if APEC was to be excluded as a framework for a pan-Pacific trading arrangement there were other ways, clearly less attractive from the East Asian point of view, by which the US could accomplish its regional trade diplomacy (Funabashi 1995:177). As US President Clinton's

5 Extending NAFTA across the Pacific was discussed as a trade policy option but not advocated by Bhagwati (1993).

6 The trade consequences for East Asia resulting from the formation of NAFTA have been estimated to be quite small. Primo Braga et al. (1994) estimate that NAFTA-induced trade diversion could cost East Asian economies between $\$ 380$ million and $\$ 700$ million. Losses would be concentrated in a few sectors, such as textiles, clothing and ferrous metals, where high US trade barriers exist. Such losses are at the most 0.8 per cent of East Asian exports to the USA. They are also but 1 per cent of the gains East Asia will receive from the successful implementation of the Uruguay Round agreements. While the Primo Braga et al. (1994) findings, if anything, are an over-estimate of the losses that might occur, their work does not address in a quantitative fashion the direct investment consequences of NAFTA's very restrictive rules of origin.

7 The scale of such diversion may be considerably less than is widely feared. While no modelling of a sequential trans-Pacific extension of NAFTA has been done, Brown et al. (1995) have looked at the growth of a trading bloc where Japan successively adds East Asian trading partners. Somewhat surprisingly a Japan-Korea trading bloc imposes only $\$ 40$ million in trade diversion on Taiwan and only a very small reduction in Taiwan's economic welfare. (Singapore actually experiences a small gain in economic welfare.) In common with Primo Braga et al. (1994), Brown et al. (1995) make no effort to estimate investment or its trade consequences. If a Korea-Japan free trade area has so little consequence for Taiwan, perhaps the same would be true if Korea and the USA followed up on the understanding reached between USTR Mickey Kantor and then Foreign Minister Han Sung Jo. 
Commission on United States Trade and Investment Policy observed in the second quarter of 1997:

Even the announcement of America's intention to create one or more bilateral free trade areas in the region could accelerate competition for scarce capital and create momentum for APEC-wide trade and investment liberalization in the region bringing the benefits of market opening to American traders all the sooner (Commission on United States Trade and Investment Policy 1997:46). ${ }^{8}$

\section{Westward expansion of NAFTA without Japan?}

Is the threat of such a US policy credible? Given the continuing US interest in such policies, this is a question worth asking. The answer may depend to a considerable degree on the ease of substitution between US and Japanese capital, management and technology in East Asian industry. It is highly unlikely that Japan would be the first East Asian economy asked to join NAFTA. ${ }^{9}$ Unless Japan joins first, however, NAFTA's restrictive rules of origin will probably necessitate a greatly increased North American presence in the economy of the pioneer East Asian NAFTA members. Over the past decade, Japan has been a more important source of direct investment in East Asia than has the USA (OECD 1996). With the exception of investment in Hong Kong, much of this investment has been in manufacturing with the greater part of it linked to export promotion rather than import substituting activities (UNCTAD 1994; MITI 1994).

The past need not be a guide to the future. While US direct investment in East Asia has lagged behind Japanese investment over this decade, the last five years have witnessed significant increases (OECD 1996). As Table 1 makes clear, US direct investment in East Asia, no less than Japanese investment, is heavily

Table 1

Investment in manufacturing as percentage of total accumulated direct investment in selected East Asian economies by Japanese and US companies, 1993

\begin{tabular}{|c|c|c|c|c|c|c|c|c|}
\hline & \multicolumn{2}{|c|}{$\begin{array}{l}\text { Electrical } \\
\text { machinery }\end{array}$} & \multicolumn{2}{|c|}{$\begin{array}{c}\text { Transportation } \\
\text { machinery }\end{array}$} & \multicolumn{2}{|c|}{ Chemicals } & \multicolumn{2}{|c|}{$\begin{array}{c}\text { Other } \\
\text { manufacturing }\end{array}$} \\
\hline & Japan & US & Japan & US & Japan & US & Japan & US \\
\hline Indonesia & 1.6 & - & 2.7 & - & 10.4 & 1.2 & 20.7 & 2.0 \\
\hline Hong Kong & 2.5 & 14.9 & - & - & 0.3 & 1.4 & 5.6 & 9.1 \\
\hline Singapore & 8.0 & 21.3 & 1.6 & - & 10.5 & 6.0 & 20.5 & 25.4 \\
\hline Thailand & 18.1 & 7.6 & 4.8 & - & 4.8 & 7.9 & 37.6 & 14.3 \\
\hline China & 13.8 & - & 2.2 & - & 2.4 & 7.6 & 24.4 & 44.9 \\
\hline Malaysia & 27.4 & 44.5 & 4.6 & - & 9.3 & 2.5 & 31.2 & 8.9 \\
\hline Korea & 11.7 & 6.2 & 6.9 & 2.0 & 10.0 & 7.1 & 18.9 & 25.9 \\
\hline Taiwan & 18.9 & 25.0 & 8.3 & - & 8.2 & 25.9 & 32.9 & 10.3 \\
\hline Philippines & 14.5 & 9.1 & 12.3 & - & 6.3 & 21.8 & 23.1 & 2.3 \\
\hline
\end{tabular}

8 The Commission on United States Pacific Trade and Investment Policy (1997:46) specifically recommends that "The US should pursue selective bilateral or plurilateral free trade areas with interested Asia Pacific partners." Similarly, the Clinton administration's 1997 Trade Policy Agenda notes, "Historically one of the best guarantors of progress in trade relations has been bilateral agreements. If done correctly, bilaterals, which are a key facet of President Clinton's trade strategy, can resolve issues quickly and set new rules and standards that can later be adopted on wide scale" (USTR 1997:II-2).

9 See the discussion in Kuroda (1989) and the USITC (1988). The Commission on United States-Pacific Trade and Investment Policy (1997:35) recommends that "the US government study the feasibility of negotiating a Comprehensive Market Agreement between Japan and the USA. Such an agreement would include all aspects of a standard free trade agreement, but would go beyond such a pact by creating agreed upon procedures with regard to investment, anti-competitive business practices, administrative procedures, and a range of other sectoral matters often identified as structural trade and investment barriers." 
committed to manufacturing. Indeed, the US and Japanese patterns of investment by industry are quite similar. The continuing US threat to expand NAFTA across the Pacific cannot be dismissed as entirely impractical.

\section{The Bogor declaration}

Whatever role the threat of the westward expansion of NAFTA might have played in the discussions leading up to the ministerial and leaders meeting in Jakarta in November 1994, the basic stance of most East Asian members at that meeting toward using APEC to negotiate a pan-Pacific PTA did not appear to change markedly. The Bogor declaration issued at the conclusion of the meeting calls for free trade in the region by 2020 with more developed economies agreeing to complete their liberalisation by 2010 (Yamazawa 1997). Significantly, subject to these final dates, the Bogor declaration has left each APEC member free to decide the pace and terms of their liberalisation. As outlined in the Action Agenda adopted at the Osaka Ministerial in 1995, APEC members are committed to communicate regularly with one another on their progress and future plans for meeting the agreed-upon final liberalisation goal. In practice, this has meant negotiations among APEC members on the form for such communication and the criteria by which trade liberalisation can be evaluated (Elek and Soesastro 1997). Interim benchmarks for member countries, for example, for tariff reduction, quota elimination and for almost all other kinds of deregulation have been scrupulously avoided (Soesastro 1995). ${ }^{10}$

\section{Europe's new Asian trade policy}

While much of the regionalism in US trade policy has been designed to cope with what are, looked at from the Western side of the Atlantic, highly parochial trade policies of the EU, the EU itself has responded with a new set of regional trade initiatives directed towards East Asia. Europe has a long history of discriminating against East Asian products in general and Japanese products in particular. ${ }^{11}$ It was only in the 1970s that most of Western Europe stopped invoking GATT's Article XXXV against Japan. ${ }^{12}$

In recent years, however, economic relations between the EU and East Asia have changed dramatically. At the end of 1993, Japan had over $\$ 78$ billion in direct investments in Europe (Okurasho 1994). ${ }^{13}$ Ninety-five per cent of this investment has been made within the past ten years. At the same time EU exports to Japan have grown fivefold, with EU exports to East Asia as a whole expanding fourfold (MITI 1994). In 1996, Europe's East Asian exports exceeded its North American exports for the first time (IMF 1997). Most significantly, the EU has made every effort to establish a distinct trade diplomacy with Japan. Despite the $\$ 60$ billion in Japanese goods sold in the EU and despite a $\$ 33$ billion trade deficit with Japan, EU trade policy has not blindly supported the US in its trade disputes with Japan. ${ }^{14}$ This

10 Unlike trade liberalisation where the form and time path of liberalisation to achieve the agreed upon APEC goal is left entirely to the discretion of the members, collective action has been taken to draft a model APEC investment code. Such a code is designed to help free the flow of direct investment throughout the Pacific. It is not intended, however, that this code have the status of an international agreement. As adopted at the Jakarta Ministerial, the code has been designated as the APEC Nonbinding Investment Principles. As its name implies, it is supposed to encourage APEC members to liberalise their policies towards foreign investment but, at present, nothing more.

11 Saxonhouse (1993c), using data from 1983, finds that Europe imports less from Japan than predicted by a factor-endowment-based gravity equation. By contrast, the USA imports more than predicted. The results for Japan generalise to all the major East Asian economies. These results are also consistent with the findings in Frankel and Wei (1995).

12 Article XXXV allows a contracting party to refuse to have its relations with another contracting party governed by the GATT.

13 The EU has taken a number of initiatives specifically designed to facilitate foreign direct investment by European firms in Asia. The most important financial assistance programs include the Asian Invest Programme, The European Community Investment Partners, and the Asian financing facility of the European Investment Bank. These programs are discussed in UNCTAD (1996).

14 For example, both Sir Leon Brittan and Jacques Santer, the current President of the EU, have explicitly criticised US trade policies toward Japan. Two days before the Clinton-Hosokawa summit in February 1994, Sir Leon denounced US demands that Japan agree to numerical targets for imports. In May and June of 1995, Sir Leon and President Santer criticised the USA for imposing sanctions on Japanese luxury automobiles without first seeking approval from the WTO. 
diplomacy has been complemented by the Kaifu-Delors-Lubbers declaration of common interests in July 1991 designed to elevate the EU-Japan trading relationship to the status of the relationship that both maintain with the USA (Nihon Keizai Shimbun 1991).

The Kaifu-Delors-Lubbers declaration has since been generalised with the organisation of the Asia-Europe Meeting (ASEM), which now brings together the leaders of ASEAN, China, the EU, Japan and South Korea on a regular biennial schedule. ASEM is a clear European response to APEC's increasingly high profile. While the development of ASEM provides East Asia with leverage vis-à-vis the USA, it also allows the prospective members of Prime Minister Mahathir's East Asian Economic Group to meet as a caucus, possibly provoking criticism from the USA (Takashi 1997). The inaugural meeting of ASEM in March 1996 in Bangkok announced the successful development of a "common vision for the future and the forging of a new comprehensive Asia-Europe Partnership for Greater Growth" (Nihon Keizai Shimbun 1996). ${ }^{15}$ Thus far, ASEM has stressed trade facilitation and investment promotion rather than trade liberalisation (Naritaka 1997). This may change with the appointment, at the next ASEM leaders meeting in London in February 1998, of a panel modelled after APEC's Eminent Persons Group. It is expected that this body will be asked to provide ASEM with a detailed vision statement.

\section{TAFTA and the new trans-Atlantic marketplace}

Given the evident US interest in establishing a preferential trading arrangement in the Pacific, EU interest in strengthening and renewing ties with East Asia is hardly surprising. More surprising, particularly in light of the stress by the leadership of the EU on the importance of maintaining and enhancing the role of the nascent WTO, was the 1995 proposal by Klaus
Kinkel in Germany and by other prominent European policy-makers for the creation of a trans-Atlantic free trade area (TAFTA). The TAFTA proposal was quickly, if cautiously, embraced by US Secretary of State Christopher. Regional trading arrangements with nonEuropean areas had first become part of US trade policy as a tactic to encourage European participation in a new round of multilateral negotiations. By the second quarter of 1995, US interest in preferential trade arrangements had come full circle, with policy-makers flirting with the notion that a PTA with Europe might possibly force a design of APEC more in accord with US preferences.

As a serious proposal, TAFTA had an extremely short life-span. Within a few months of its original conception, US and EU officials announced that they were "not in a position to launch a full blown free trade area... [the TAFTA proposal] raised many problems, including the need to make such a process compatible with World Trade Organisation rules as well as its potential impact on various economic sectors" (Business Times 1995:14). In place of TAFTA, US and EU officials are now considering a more modest proposal for creating a New Trans-Atlantic Marketplace (NTM). US and EU officials envision NTM as a forum for strengthening ties between American and European government officials and business executives with an eye towards further eliminating trade barriers. At a summit meeting in December 1995, President Clinton, EU President Jacques Santer and Spanish Prime Minister Felipe Gonzalez agreed to authorise a study by the newly created Trans-Atlantic Business Dialogue (TABD) on ways to facilitate trade in goods and services between the USA and the EU and further reduce tariffs and non-tariff barriers. As an interim objective the hope was expressed that an agreement on the mutual recognition of product standards might be reached and that particular support be given to the efforts of the OECD to develop a comprehensive international investment code

15 It is also expected that the London Leaders Meeting will assess progress on ASEM initiatives at trade facilitation, educational exchange and the identification of trade and investment barriers (Nihon Keizai Shimbun 1997). Some observers suggest the main ASEM accomplishment since its inaugural meeting in March 1996 has been EU-Asian co-operation in WTO financial services negotiations (Far Eastern Economic Review 1997). 
(Inside US Trade 1995a). ${ }^{16}$ Having hoped that the prospect of a TAFTA might push APEC to transform itself into a PTA, American officials have found a formal PTA is no more possible with the EU than it is with East Asia.

\section{APEC's East Asian members and reciprocity}

US trade policy of the past dozen years smacks more of Metternich than of John Stuart Mill. While US trade policy may have successfully encouraged the launching of the Uruguay Round and may have helped to bring it to a successful conclusion, it has also been successful in forming a preferential trading area in North America and in helping to promote APEC. The various twists and turns of US trade policy thus far have not been successful, however, in encouraging the transformation of APEC into a pan-Pacific PTA. Whatever liberalisation has thus far been stimulated by APEC, the individual market-opening action plans (IAPs) tabled by member-states at the 1995 APEC meeting in Osaka, and subsequently improved upon at Manila, have all been framed on a WTO-consistent, unconditional most-favourednation basis (Elek and Soesastro 1997).

Why is it that most of APEC's East Asian members have been so resistant to the creation of a Pacific PTA? The American-led Eminent Persons Group, arguing against unconditional MFN, noted:

...considerations suggest that, while APEC members should implement unilateral liberalization to the maximum extent possible, it will be expedient to pursue a strategy of negotiated liberalization as well. The largest members, including the United States, are unlikely to liberalize unilaterally when they can use the high value of access to their markets to obtain reciprocal liberalization from others. The same view applies to other economies in the region.

The closely related consideration is that APEC as a whole is the world's largest trading region, considerably larger than even the EU...the region would give away an enormous amount of leverage if its members... especially its largest members-were to liberalize unilaterally to any significant degree (APEC 1994:29).

Unlike the USA, many of the East Asian APEC members see the commitment to free trade in the area by 2020 as little more than a commitment to continue, with region-wide encouragement, the largely unilateral liberalisation that has been under way for more than a decade (Drysdale and Elek 1996). All the major economies in the Western Pacific have undergone major changes in their trade regime with large reductions in their effective rates of protection and their non-tariff barriers. ${ }^{17}$

From the perspective of the Western Pacific, unilateral liberalisation has been viewed as having quite tangible consequences (Drysdale and Garnaut 1993). Over the past two decades, trade liberalisation in the major East Asian economies, in particular, has been associated with rapid economic growth. East Asian liberalisation of foreign investment rules is widely believed to have influenced economic growth by encouraging a rapid acceleration in the inflow of technology-enhancing productivityimproving foreign direct investment. In East Asia, great emphasis has been placed on the role of foreign direct investment in stimulating economic growth, even though it constitutes a very small proportion of gross domestic capital formation in almost all of these economies (UNCTAD 1996). It is this confidence in the role that foreign direct investment can play in improving economic well-being that has led East Asian economies to accelerate their removal of restrictions in the hope of attracting still more such investment. This liberalisation of foreign investment restrictions, which has also motivated the liberalisation of trade barriers, has been done unilaterally and competitively among the various East Asian economies (Soesastro 1996).

16 Since the Seville summit, the TABD has played a role in promoting the new barrier-eliminating Information Technology Agreement (USDC 1996). Like APEC, TABD claims credit for the successful conclusion of this complex negotiation.

17 See the evidence in Kwak (1994); Urata and Yokota (1994); Okamoto (1994); Warr (1992); GATT (1991); IAC (1988); Bates and White (1988); and PECC (1995). 
Table 2

Remaining restrictions on foreign investment maintained by East Asian APEC members

(1) Limitations on foreign ownership

$\begin{array}{lll}\text { China } & \text { Malaysia } & \text { Taiwan } \\ \text { Indonesia } & \text { Philippines } & \text { Thailand } \\ \text { Korea } & \text { Singapore } & \end{array}$

(2) Restrictions on landownership

Brunei Indonesia Taiwan

China Philippines Thailand

(3) Restricted sectors

China Philippines Taiwan

Indonesia Singapore Thailand

Malaysia

(4) Performance requirements

$\begin{array}{lll}\text { China } & \text { Malaysia } & \text { Taiwan } \\ \text { Indonesia } & \text { Philippines } & \text { Thailand } \\ \text { Korea } & & \end{array}$

(5) Tax incentives

China Malaysia Singapore

Korea Philippines Thailand

(6) Licensing

$\begin{array}{lll}\text { Brunei } & \text { Korea } & \text { Singapore } \\ \text { China } & \text { Malaysia } & \text { Taiwan } \\ \text { Indonesia } & \text { Philippines } & \text { Thailand }\end{array}$

(7) Foreign exchange control

China Korea Taiwan

Source: APEC 1995c.

Given the stress that most of East Asia's APEC members have placed on liberalisation and deregulation as a key element in their economic strategy, joining any arrangement that might in any way constrain their freedom of action is not a step taken lightly. Two considerations are particularly important. First, while joining a pan-Pacific PTA might aid in extracting market access concessions from non-members such as the EU, the risk of failure is non-trivial for APEC's East Asian members. Despite the high proportion of intra-APEC trade, its East Asian members' interests are fundamentally global. By itself, the EU rivals the USA as a large market for East Asia. Second, as seen in Table 2, impressive as the liberalisation of foreign direct investment undertaken so far has been, East Asian members of APEC have been reluctant to give up sovereignty in this area. They apparently wish to continue to control the pattern of liberalisation no matter how fast the overall pace may be.

\section{The economics and politics of unilateral liberalisation}

If, in recent years, economies in the Western Pacific by and large have pursued the liberalisation of their foreign investment and trade regimes unilaterally and if these changes are viewed as highly successful, is there any reason why they should now abandon these policies and join a preferential trading arrangement? There is a significant literature in economics designed to answer this question, at least insofar as trade is concerned. As noted above, the Eminent Persons Group Report, in advocating what amounts to a PTA, stressed the argument that market power will make the PTA superior to unilateral liberalisation because of terms-of-trade effects. This argument appears at variance with the traditional finding that when small countries which face exogenously determined prices join a preferential trading arrangement it is usually dominated by unilateral liberalisation (de Melo et al. 1993). In fact, it is not necessarily at variance at all. The Eminent Persons Group presumably had in mind a case where, in the presence of another group of countries maintaining substantial protection, it can be welfare-enhancing for small countries to band together into a PTA in the interest of improving the terms of trade (Wonnacott and Wonnacott 1981; de Melo et al. 1993). The relevance of this particular case is questionable. As de Melo et al. note:

... if the world gets divided into inwardlooking blocs, [unilateral trade liberalisation] will become a less attractive option for countries outside the bloc than it is today. The [small] countries will then be better off, either seeking access to one of the blocs and adopting its trade policy or engaging in [regional integration] so as to promote freer trade among themselves. Of course, the current world being quite far from consisting of closed blocs, the example does not justify a preference for 
[regional integration] over [unilateral trade liberalisation] (de Melo et al. 1993:168).

Given that most of the economies of East Asia and Oceania view themselves as price-takers perhaps it is not surprising that they resist joining a PTA.

The trade models just referred to abstract from political considerations. The political decision on whether to join a PTA has also been modelled. An important strand of this literature treats interest groups as participants in a competition for political favours that are meted out by politicians serving their own selfish interests (Grossman and Helpman 1995). This competition is part of one of two distinct stages of strategic interaction in the decision-making process. One of these stages is domestic and the other international; neither stage can be analysed without the other. As Grossman and Helpman (1995:668) note, "International interdependence sets the parameters for the domestic political context, while the domestic political environment constrains the actions that governments can take internationally." Unsurprisingly, analysis of such processes finds that the conditions which would make it politically possible for a country to join a PTA are often the same conditions that make it economically not in its interest to join (for example, large trade diversions).

Unilateral trade liberalisation, by definition, is unconstrained by the demands of international reciprocity. If getting political support for joining a PTA may result in an outcome that is not in a country's economic interest, it is also possible that unilateral trade liberalisation can be consistent with developing significant support for liberal trade. The absence of foreign constraints is not inevitably a problem for political leaders seeking to build a constituency for economic liberalisation. Foreign demands for liberalisation can be useful in breaking apart recalcitrant domestic coalitions: for example, gaiatsu (foreign pressure) on Japan. Alternatively, such demands can be economically and politically unreasonable: as, on some occasions, demands for voluntary import expansions have been. Even under conditions where joining a PTA might offer more in the way of export opportunities than unilateral trade liberalisation, in some instances East Asian trade policy-makers may do better for the welfare of their economies by having the freedom to design liberalisation packages facing only domestic constraints. This, in fact, is the conclusion many East Asian policy-makers have reached.

\section{US views on East Asian liberalisation}

At least part of the impatience of US trade negotiators with the unwillingness of most other APEC members to join a PTA stems from a different perception of the liberalisation process there. The Report of the American-led Eminent Persons Group remarks in its critique of unilateral liberalisation that "effective protection remains high in the region despite the liberalisation" (APEC 1994:28). The very large bilateral trade surpluses that most of the East Asian economies maintain with most of their non-oil trading partners are viewed not as an indication of thrift but, wrongly, as the product of onerous trade barriers. ${ }^{18}$

For example, US trade policy-makers have been too pre-occupied with Japan's trade surpluses to appreciate the extraordinary changes that have occurred in its economy. 19 Despite the endless bilateral negotiations with the USA, Japan instituted the vast majority of those changes because it was in Japan's own economic interest to do so. The US refusal to accept the fact of Japan's liberalisation may well be repeated elsewhere. Indeed, the Clinton administration has rationalised its aggressive unilateral policy towards Japan by arguing that it needs to show the rest of East Asia that the USA will not tolerate any emulation of Japan's 'restrictive policies'.

18 These very large bilateral trade imbalances made it unlikely that the USA could conclude a preferential trading arrangement with East Asia even if the majority of East Asian economies were so inclined. See Grossman and Helpman (1995).

19 Some evidence on this is provided in Saxonhouse (1993d; 1994a; 1994b, particularly Table 5). 


\section{Osaka, Manila and the future of APEC}

In the second quarter of 1995, the American trade negotiators were willing to ignore WTO dispute resolution procedures. This helped undercut whatever chance there might have been that most East Asian members of APEC would agree to enter into formal negotiations for a PTA under the auspices of WTO's Article XXIV. In many quarters in East Asia it is now widely believed that the best protection against US unilateralism may well be the EU, the one significant economic grouping excluded from APEC. This is ironic in view of the history of European-East Asian trade diplomacy before 1991 (Saxonhouse 1993b, 1993c).

Given that an informal consensus appears to have been reached at Osaka and Manila that no attempt will be made in the foreseeable future to notify the WTO under Article XXIV that a preferential trading arrangement is being negotiated, any APEC liberalisation which is not offered on an unconditional MFN basis to all WTO members will be a violation of the WTO's Article I. ${ }^{20}$ In consequence, all individual action plans (IAPs) for comprehensive liberalisation so far tabled have been framed by APEC member-states as unconditional MFN plans. This pattern is unlikely to change in the foreseeable future. ${ }^{21}$

In addition to the apparent consensus that there will no APEC negotiations under WTO provisions governing PTAs, another informal consensus reached at both Osaka and at Manila holds that any formal WTO-style negotiations at all should be avoided. In the months prior to the Osaka Ministerial and Leaders Meeting, US negotiators had hoped to get an agreement that APEC member liberalisation plans, when finally offered, would be strictly comparable with one another. With acceptance of the principle of strict comparability, formal negotiations would almost inevitably have followed. In its final version, however, the Action
Agenda adopted at Osaka only committed members "to endeavour to insure the overall comparability of their trade and investment liberalization and facilitation" (APEC 1995b:1).

The same desire to avoid formal negotiations is also behind the consensus specifically reached at Osaka on how to combine comparability of liberalisation with the very diverse circumstances of APEC members. In particular, Japan, China, Taiwan and Korea have all been eager that APEC's Action Agenda allow for special treatment of sensitive sectors, such as agriculture. US negotiators have opposed such special treatment, arguing it is inconsistent with the Bogor declaration's commitment to free trade in the Asia-Pacific by 2020. US opposition has not been sufficient to prevent the Action Agenda from agreeing that "given the diverse circumstances in the APEC economies flexibility will be available in dealing with issues arising from such circum- stances in the liberalisation and facilitation process" (Inside US Trade 1995b:11). The adoption of this language is taken by many East Asian members of APEC to mean that free trade in the Asia-Pacific by 2020 does not necessarily mean zero tariffs in all sectors by 2020 (Nihon Keizai Shimbun 1995).

\section{Finale}

The outcome of fifteen years of US pursuit of regional trade policies could possibly be a network of preferential trade arrangements centred around the USA. If the US experience in Asia is any guide, a more likely outcome than an American-centred hub-and-spoke system is an increasingly strengthened multilateral system based on the WTO. Given the experience of the US-Japan auto parts dispute in the spring of 1995, it is now widely believed in East Asia that the best hope for parrying US pressure is in the WTO where the EU maintains a substantial balancing presence. The EU is willing to play this role because of its interest in

20 The decision at Osaka to disband the Eminent Persons Group, which had been forcefully pushing for liberalisation based on conditional MFN plans, is symbolic of this new consensus.

21 In the absence of new fast-track negotiating authority from the Congress, the USA is constrained from negotiating new agreements on a conditional MFN basis. From the Uruguay Round, the USTR does retain residual authority to negotiate unconditional MFN agreements for a few sectors. 
the growing economic opportunities in East Asia and because of its suspicions of US bilateralism. $^{22}$ As if to underline the overwhelming primacy of WTO obligations, the APEC meeting in Osaka effectively rejected the recommendation of the Eminent Persons Group for a dispute mediation service. ${ }^{23}$ According to the clear consensus reached at Osaka and Manila, nothing should be done that would in any way undercut the WTO's newly strengthened dispute settlement mechanism.

What began as realpolitik may well end up conforming to the visions of Immanuel Kant and Woodrow Wilson. The US plunge into PTAs may well be leading to a much stronger, broadly-based multilateral system, whatever current US government preferences might be. A stronger WTO may prove capable of constraining even its most powerful members. The international economic transactions, even of the countries who need the system least in the short run, may come to be strictly governed by international law. This outcome is certainly in the long-term interest of the USA.

\section{References}

Anderson, Kym and Snape, Richard N. 1994. "European and American regionalism: effects on and options for Asia", Journal of the Japanese and International Economies, 8(4):454-77.

APEC (Asia Pacific Economic Cooperation). 1994. Achieving the APEC Vision: second report of the Eminent Persons Group, APEC, Singapore.

— 1995a. Foreign direct investment and APEC economic integration, APEC Working Paper \#95-EC-01, APEC, Singapore.

_ 1995b. The Osaka Action Agenda: implementation of the Bogor declaration, APEC, Singapore.

- 1995c. Survey of impediments to trade and investment in the APEC region, APEC Working Paper \#95-CT-01.2, APEC, Singapore.

- - 1995d. Implementing the APEC Vision: the third report of the Eminent Persons Group, APEC, Singapore.

1997. APEC Chairman's Statement, Montreal, Canada, 8-10 May, APEC, Singapore.

Bates, W. and White, G. 1988. Industry Assistance Reform in New Zealand, The Treasury, Wellington.

Bergsten, C. Fred. Forthcoming. "Open regionalism", World Economy.

Bhagwati, Jagdish. 1993. “NAFTA: Clinton's trading choices", Foreign Policy 91(summer):155-63.

Bhagwati, Jagdish, and Panagariya, Arvind. 1996. "The theory of preferential trade agreements: historical evolution and current trends", American Economic Review, 86(2):82-7.
Brown, Drusilla K.; Deardorff, Alan V. and Stern, Robert M. 1995. The economic effects of an East Asian trading bloc, Research Forum on International Economics Discussion Paper No. 381, University of Michigan Institute for Public Policy Studies, Ann Arbor.

Business Times. 1995. “TAFTA concept fails to generate support", Leon Hadar, 31 July, p. 14.

Commission on United States-Pacific Trade and Investment Policy. 1997. Building American Prosperity in the $21^{\text {st }}$ Century, Commission on United States-Pacific Trade and Investment Policy, Washington, DC.

De Melo, Jaime; Panagariya, Arvind and Rodrik, Dani. 1993. "The new regionalism: a country perspective", chapter 6 in de Melo, Jaime and Panagariya, Arvind (eds), New Dimensions in Regional Integration, Cambridge University Press for the World Bank and CEPR, Cambridge.

Drysdale, Peter and Elek, Andrew. 1996. “The APEC experiment: an open economic association in the Asia Pacific", International Journal of Social Economics, 23(4,5,6):164-87.

Drysdale, Peter and Garnaut, Ross. 1993. “The Pacific: an application of a general theory of economic integration", in Bergsten, C. Fred and Noland, Marcus (eds), Pacific Dynamism and the International Economic System, Institute for International Economics, Washington,DC,pp. 188-223.

22 In other contexts in the WTO, the USA plays a similar balancing role vis-à-vis the EU, a fact apparently also widely appreciated in East Asia.

23 At the Jakarta Ministerial in 1994, the American-led Eminent Persons Group proposed a dispute resolution mechanism in connection with the APEC nonbinding investment principles. Fearing US domination, Western Pacific APEC members preferred arbitration procedures consistent with members' existing international commitments. 
Elek, Andrew and Soesastro, Hadi. 1997. ASEAN, APEC and ASEM: concentric and circles and 'open clubs', The Australian National University, Canberra. Forthcoming in ISIS Issue Paper series, ISIS, Kuala Lumpur.

Far Eastern Economic Review. 1997. “Europe and Asia can be closer", Leon Brittan, 20 February, p. 31.

Ellis, Howard S. 1945. Bilateralism and the Future of International Trade, International Finance Section, Department of Economics, Princeton University, Princeton, NJ.

Frankel, Jeffrey and Wei Shang-Jin 1995. "The new regionalism and Asia: issues and impacts", paper prepared for the Conference on Emerging Global Trading Environment and Developing Asia, Manila, May.

Funabashi, Yoichi. 1995. Asia Pacific Fusion: Japan's role in APEC, Institute for International Economics, Washington, DC.

GATT (General Agreement on Tariffs and Trade). 1991. Trade Policy Review: Indonesia, 1991, GATT, Geneva.

Grossman, Gene and Helpman, Elhanan. 1995. “The politics of free trade agreements", American Economic Review, 85(4):667-90.

IAC (Industries Assistance Commission). 1988. Annual Report 1987-1988, AGPS, Canberra.

Inside US Trade. 1995a. "US-EU action plan includes broad agenda", 13(44).

__ 1995b. "Kantor downplays significance of flexibility principle", 13(47):11.

IMF (International Monetary Fund). 1997. Direction of Trade Quarterly, June, Washington, DC.

Krugman, Paul R. 1991. "Is bilateralism bad?", chapter 1 in Helpman, Elhanan and Razin, Assaf (eds), International Trade and Trade Policy, MIT Press, Cambridge.

Kuroda, Makoto. 1989. "Strengthening Japan-US cooperation and the concept of Japan-US free trade arrangements", in Schott, Jeffrey J. (ed.), Free Trade Areas and US Trade Policy, Institute for International Economics, Washington, DC, pp. 121-30.

Kwak Hyun-Tae. 1994. "Changing trade policy and its impact on TFP in the Republic of Korea", Developing Economies, 32(4):398-422.

Lipsey, Richard G. 1990. Canada and the US-Mexico Free Trade Dance: wallflower or partner?,C. D. Howe Institute, Toronto.

Manning, Robert A. and Stern, Paula. 1994. "The myth of the Pacific community", Foreign Affairs, 73(6):79-93.

MITI (Tsushosangyosho). 1994. MITI White Paper (Tsusho hakusho rokunen), MITI, Tokyo.
Naritaka, Nakaishi. 1997. "Economic study of ASEM", Journal of Japanese Trade and Industry, 16(4):12-17.

Nihon Keizai Shimbun. 1991. "Japan-EC declaration calls for equitable trade", Akira Kojima, p. 2, 27 July. -1994. "South Korea, US to mull over trade accord", 3 May.

1995. "Murayama avoids direct commitment to free trade in rice", 19 November.

1996. "Asia-Europe summit forges new partnership", 2 March.

_ 1997 “While Asian, EU ministers argue politics, money talks", 20 February.

Okamoto, Yumiko. 1994. "Impact of trade and liberalization policies in the Malaysian economy", Developing Economies, 32(4):460-78.

Okurasho. 1994. Kokusai kinyu nenpo 1994, Tokyo.

OECD (Organisation for Economic Cooperation and Development). 1996. International Direct Investment Statistics Yearbook, OECD, Paris.

PECC (Pacific Economic Cooperation Council). 1995. Survey of Impediments to Trade and Investment in the APEC Region, PECC, Singapore.

Petri, Peter. 1993. "The East Asian trading bloc: an analytical history", chapter 1 in Frankel, Jeffrey A. and Kahler, Miles (eds), Regionalism and Rivalry, University of Chicago Press for the National Bureau of Economic Research, Chicago.

Primo Braga, Carlos A.; Safadi, Raed and Yeats, Alexander. 1994. NAFTA's implications for East Asian exports, Policy Research Working Paper No. 1351, World Bank, Washington, DC.

Saxonhouse, Gary R. 1993a. "Trade blocs and East Asia", chapter 12 in de Melo, Jaime and Panagariya, Arvind (eds), New Dimensions in Regional Trade Integration, Cambridge University Press for the World Bank and the Center for Economic Policy Research, Cambridge.

Saxonhouse, Gary R. 1993b. "Pricing strategies and trading blocs in East Asia", chapter 3 in Frankel, Jeffrey and Kahler, Miles (eds), Regionalism and Rivalry: Japan and the US in Pacific Asia, University of Chicago Press for the National Bureau of Economic Research, Chicago.

Saxonhouse, Gary R. 1993c. "Europe's economic relations with Japan", in Adams, William James (ed.), Singular Europe, University of Michigan Press, Ann Arbor, pp. 347-70.

Saxonhouse, Gary R. 1993d. "What does Japanese trade structure tell us about Japanese trade policy", Journal of Economic Perspectives, 7(3):21-43.

Saxonhouse, Gary R. 1994a. The Economics of the US-Japan Framework Talks, Hoover Essays in Public Policy No. 53, Hoover Institution Press, Stanford, CA. 
Saxonhouse, Gary R. 1994b. Japan and the 1994 economic report of the President, Research Seminar in International Economics Discussion Paper No. 387, University of Michigan, Ann Arbor.

Snape, Richard H. 1996. "Trade discriminationyesterday's problem", Economic Record, 72(219): 380-96.

Soesastro, Hadi. 1995. "The APEC nonbinding investment principles", NBR Analysis, 6(1)62-9:

Soesastro, Hadi. 1996. Policies of Asian Developing Countries Towards Direct Investment, Center for Strategic and International Studies, Jakarta.

Takashi, Sadahiro. 1997. "Outline of ASEM: the regional forum as a jealousy-driven mechanism", Journal of Japanese Trade and Industry, 16(5):8-11.

Thurow, Lester C. 1992. Head to Head: coming economic battles among Japan, Europe and America, Morrow, New York.

UNCTAD. 1994. World Investment Report, UNCTAD, New York.

UNCTAD. 1996. World Investment Report, UNCTAD, New York.

USDC (United States Department of Commerce). 1994. Survey of Current Business, 74(7):157. 1996. TABD Progress Report, 23 May, USDC, Washington, DC.
United States International Trade Commission. 1988. Pros and cons of initiating negotiations with Japan to explore the possibility of a United States-Japan free trade area agreement: report to the Senate finance committee, United States International Trade Commission, Washington, DC.

USTR (United States Trade Representative). 1997. 1997 trade policy agenda, USTR, Washington, DC.

Urata, Shujiro and Yokota, Kazuhiko.1994. “Trade liberalization and productivity growth in Thailand", Developing Economies, 32(4):444-59.

US Department of State Dispatch. 1993. "APEC economic leaders' vision statement", 4:833-4, US Department of State, Washington, DC.

Warr, P. G. 1992. "Comparative advantage and protection in Indonesia", Bulletin of Indonesian Economic Studies, 28(3):41-70.

Wonnacott, Ronald J. 1990. Canada and the US-Mexico Free Trade Negotiation, C. D. Howe Institute, Toronto.

Wonnacott, Paul and Wonnacott, Ronald. 1981. "Is unilateral tariff reduction preferable to a customs union? The curious case of the missing foreign tariff", American Economic Review, 71(4):704-14.

Yamazawa, Ippei. 1997. "APEC's liberalization agenda and the WTO system: Japan's role and priorities", in The Emerging WTO System and Perspectives from East Asia, Korea Economic Institute of America, Washington, DC. 